\title{
Nitrogen Fertilizer Use Efficiency of Pepper as Affected by Irrigation and Fertilization Regime
}

\author{
Vjekoslav TANASKOVIK ${ }^{1 *}$, Ordan CUKALIEV ${ }^{1}$, Rameshwar S. KANWAR ${ }^{2}$, \\ Lee K. HENG ${ }^{3}$, Mile MARKOSKI ${ }^{1}$, Velibor SPALEVIC ${ }^{4}$
}

\author{
${ }^{1}$ University St. Cyril and Methodius, Faculty of Agricultural Sciences and Food, Blvd. Aleksandar Makedonski bb, 1000, Skopje, Republic of Macedonia; \\ vjekoslavtanaskovic@yahoo.com;vtanaskovic@zf.ukim.edu.mk (*correspondingauthor); cukaliev@gmail.com;mile_markoski@yahoo.com \\ ${ }^{2}$ Iowa State University of Science and Technology, Department of Agricultural and Biosystems Engineering, 4358 Elings Hall, Ames, \\ LA50011,Iowa,U.S.A.; rskanwar@iastate.edu \\ ${ }_{3}^{3}$ International Atomic Energy Agency, Joint FAO/LAEA Division of Nuclear Techniques in Food and Agriculture, PO Box 100, \\ Wagramer Strasse 5 A-1400 Vienna, Austria; L.Heng@iaea.org \\ ${ }^{4}$ University of Montenegro, Biotechnical Faculty, Department of Soil Science, Podgorica, Mihaila Lalica, 81000 Podgorica, Montenegro; velibor.spalevic@gmail.com
}

\begin{abstract}
The pepper producers in the Republic of Macedonia have used drip irrigation systems to increase yield in recent years, but more research is still needed, related to irrigation scheduling and precise requirement of nitrogen fertilizer to maximise pepper yield. Therefore, a two year experiment was conducted in a plastic house to determine the nitrogen fertilizer use efficiency (NFUE) and yield potential of pruned pepper as affected by irrigation and fertilization regime. Four experimental treatments were applied in this study. Three of the treatments were drip fertigated $\left(\mathrm{DF}_{1}, \mathrm{DF}_{2}, \mathrm{DF}_{3}\right)$, while the fourth treatment was furrow irrigated with conventional fertilization $\left(\emptyset_{\mathrm{B}}\right)$. The labelled urea with $1 \%$ concentration of a stable isotope of nitrogen $\left({ }^{15} \mathrm{~N}\right)$ was applied for determination of NFUE. The results of this study clearly showed that increased NFUE and pepper yield depend on irrigation and fertilization regime. Namely, NFUE was significantly increased with the application of nitrogen fertilizer through drip irrigation system as compared to conventional fertilization with furrow irrigation. Also, drip fertigation frequency positively affects percentage increase of NFUE. Furthermore, our results showed that drip fertigation treatments resulted in significantly higher pepper yields in comparison to conventional fertilization. Also, drip fertigation frequency at four and two days $\left(\mathrm{DF}_{2}\right.$ and $\left.\mathrm{DF}_{1}\right)$ resulted in higher yields when compared with drip fertigation scheduled by using tensiometers $\left(\mathrm{DF}_{3}\right)$. Generally, to reach acceptable pepper yield with high NFUE, we recommend drip fertigation with a frequency of two to four days combined with two main shoots of pruned pepper in order to increase farmer's income and to minimize the environmental impact.
\end{abstract}

Keywords: drip fertigation, furrow irrigation, labelled urea, nitrogen uptake, yield

\section{Introduction}

Irrigation is the most significant input in agricultural activities to improve the yields. Throughout the world, about $70 \%$ of available water resources are allocated to agricultural activities, especially to irrigation. Today, it is almost impossible to increase the cultivated lands without irrigation, therefore researches have to do research on water management to improve unit area-yields to increase the total yields (Kirnak et al., 2016). Pepper is one of the most important vegetable crops produced under irrigated agriculture (Rubio et al., 2003). It has been observed that pepper production is confined to the warm and semi-arid countries where water is often a limiting factor for production, necessiting the need to optimize water management (Dorji et al., 2005). Furthermore, pepper is among the most sensitive horticultural plants to water deficit stress (Delfine et al., 2002; Ferrara et al., 2011). Such sensitivity was reported in some studies on the fresh and dry matter yield reductions as affected by different irrigation techniques and regime (Antony and Singandhupe, 2004; Sezen et al., 2006; González-Dugo et al., 2007; Candido et al., 2009; Kurunc et al., 2011; Aladenola and Madramootoo, 2014; Sezen et al., 2014; Sezen et al., 2015; Kuşçu et al., 2016). Also, nitrogen is another limiting factor along with water deficit in arid and semi-arid regions (Cetin and Akinci, 2015). Generally, the low pepper yield may be related with water stress or inadequate soil nutrient (Wiertz and Lenz, 1987; Abayomi et al., 2012). Compared to other agricultural crops, vegetables have very high demands for available nutrients in the soil (Smatanová, 2004). Therefore, very high nitrogen fertilization is often applied in order to promote high quality and 
Table 1. Type and amount of fertilizers used in drip fertigation treatments in $\mathrm{kg} \mathrm{ha}^{-1}$

\begin{tabular}{lcl}
\hline Type of fertilizers & Amount of applied fertilizer & Period of application \\
\hline $15: 15: 15$ & $318 \mathrm{~kg} \mathrm{ha}^{-1}$ & before transplanting \\
$0: 52: 34$ & $375 \mathrm{~kg} \mathrm{ha}^{-1}$ & drip fertigation during the vegetation \\
$0: 0: 51+18 S$ & $802 \mathrm{~kg} \mathrm{ha}^{-1}$ & drip fertigation during the vegetation \\
$46: 0: 0$ & $952 \mathrm{~kg} \mathrm{ha}^{-1}$ & drip fertigation during the vegetation \\
\hline
\end{tabular}

${ }^{*}$ Remark: the same amounts and quantity of fertilizers were used for furrow irrigation treatment

yield in pepper and other vegetable crops (Li et al., 2001; Yasuor et al., 2013; Ouzounidou et al., 2013; Fan et al., 2015). In addition, the risk of leaching of nitrate nitrogen increases because application rate in many vegetable growing areas often exceed crop demand and it is accompanied with intensive soil washing (Candido et al., 2009). When nitrogen is not properly managed, up to $70 \%$ can be lost in irrigated fields (Roberts, 2008). Improved nitrogen management has become essential in recent years; therefore inappropriate use of nitrogen fertilizers causes not economic loss, but also increases the possibility for environmental pollution (Zhu et al.,2005; Stagnari and Pisante, 2012).

Pollution by fertilizers is becoming a universal problem, which needs new approaches in order to be alleviated and to be controlled over a long period of time. According to Kubešová et al. (2014), fertilization technology has always been critical in ensuring nitrogen to be used efficiently. Therefore, fertilizer experiments using fertilizer labeled with stable isotopes provide a direct and quick means of obtaining conclusive answers to these questions (Zapata and Hera, 1997).

Pepper is one of the main vegetable crops for open field and protected environment in the Republic of Macedonia with 8,522 hectares and production of 175,867 tonnes per year (State Statistical Office, 2015). The majority of the pepper and vegetable producers in the country, especially small-scale or low-input growers, apply fertilizers in two portions, as a preplant application and during the growing season by spreading of fertilizer on soil with furrow irrigation, with risks of significant nitrogen losses. Even if drip fertigation is used, still, there are problems especially related to the irrigation scheduling, as well as to the proper use of water and fertilizers, as reported by Tanaskovik et al. (2011). Furthermore, limited results for influence of irrigation and fertilization regime on nitrogen fertilizer use efficiency (NFUE) in pepper are available in the country. Therefore, the primary objectives of this study were to compare irrigation and fertilization regimes for pepper crop in order to improve NFUE and pepper yield. In addition, to determine the effect of drip fertigation frequency on NFUE and yield was one of the aims of this study. One of the goals of this study is to provide opportunities to pepper producers in similar regions of Republic of Macedonia and other parts of the world not only to improve drip fertigation, but also to reduce the cost of production and improve environmental quality from fertilizer pollution.

\section{Materials and Methods}

\section{Experimental site and soil characteristics}

The field experiment was conducted with pepper crop (Capsicum annum L. cv. 'Duga Bela') pruned at two main shoots (V system) and grown in experimental plastic house $(9$ $\mathrm{m}$ width $\times 12 \mathrm{~m}$ length $\times 4.5 \mathrm{~m}$ height) at the Faculty of Agricultual Sciences and Food, University of Ss. Cyril and Methodius, Republic of Macedonia (NL 42 $00^{\prime}$, EL 21 ${ }^{\circ} 27^{\prime}$ ), during two consecutive crop seasons. In both the years, pepper seedlings produced by official producer in the country were used

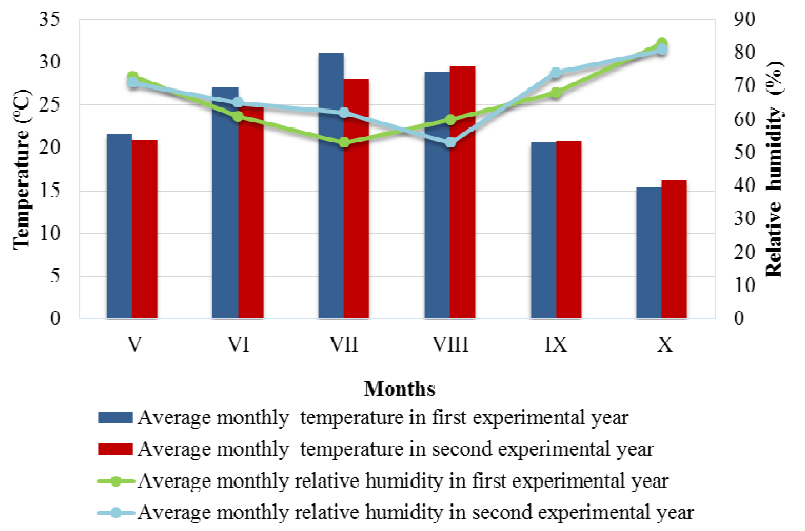

Fig. 1. Average monthly air temperature and relative humidity in experimental plastic house

for planting which was carried out on May $5^{\text {th }}$. The soil type of experimental field is Fluvisol (WRB, 2015) with average field capacity at $60 \mathrm{~cm}$ depth of $30.31 \%$ (Bar Pressure Plate Extractor 532-100, Ele International) permanent wilting point of $12.61 \%$ (Bar Pressure Plate Extractor 532-120, Ele International), and soil bulk density of $1.52 \mathrm{~g} \mathrm{~cm}^{-3}$ (Sample ring kit with closed ring holder, Eijkelkamp Soil and Water). The average soil $\mathrm{pH}$ at 0 to $60 \mathrm{~cm}$ depth was 7.30 (laboratory pH Meter-765, Knick), while soil electrical conductivity ECe was $2.31 \mathrm{dS} \mathrm{m}^{-1}$ (laboratory Conductivity Meter-703, Knick). The contents of easily accessible P (UV/VIS Spectrophotometry 6305, Jenway) and K (Flame Photometer 500-731, Jenway) are $58 \mathrm{mg} \mathrm{kg}^{-1}$ and 187 $\mathrm{mg} \mathrm{kg}{ }^{-1}$, respectively. According to the literature data for the region (Lazić et al., 2001), pepper planted in our conditions and yields up to $60 \mathrm{tha}^{-1}$ need the following amount of nutrients: 485 $\mathrm{kgha}^{-1} \mathrm{~N}, 110 \mathrm{~kg} \mathrm{ha}^{-1} \mathrm{P}$ and $485 \mathrm{kgha}^{-1} \mathrm{~K}$. The application of the fertilizer for the treatments was done in two portions, which is a common practice among farmers in the Republic of Macedonia. The first application of fertilizers was applied before transplanting of pepper, while the remaining amount of fertilizers was applied through the fertigation system for drip fertigation treatments (Table 1) and conventional fertilization for the control treatment (in two applications, one application at flowering and second application at fruit formation). Namely, all investigated treatments have received same amount of fertilizers, but with different methods and frequency of application. According to the principles of applications of isotopes in fertilizer experiments by International Atomic Energy Agency-IAEA (2001), the labelled urea with concentration of $1 \%$ of a stable isotope of nitrogen was applied for determination of NFUE in our research.

\section{The meteorological conditions during the research}

The average seasonal temperature in the experimental plastic house in the first and second experimental year was $24.1^{\circ} \mathrm{C}$ and $23.4^{\circ} \mathrm{C}$ respectively (Fig. 1). During the period of 
Table 2. Long-term average daily and monthly evapotranspiration $(\mathrm{mm})$ for pepper in Skopje region calculated by FAO software CROPWAT

\begin{tabular}{lcccccc}
\hline Months & May & June & July & August & September & October \\
\hline $\mathrm{mm} /$ day & 1.9 & 3.6 & 5.5 & 5.0 & 3.7 & 1.8 \\
$\mathrm{~mm} /$ monthly & 59 & 108 & 171 & 155 & 111 & 54 \\
\hline
\end{tabular}

the biggest fructification (June-August), the average temperatures were in the frame of the optimum values recommended by Lazić et al. (2001). Data for relative air humidity are shown in Figure 1. Except for October, the average relative humidity during the investigation was close to the recommended values for pepper production in controlled environment (Penella et al., 2014).

\section{Experimental design and treatments}

The drip irrigation system was designed according to the objectives of the study. Polyethylene pipe with $32 \mathrm{~mm}$ diameter was used as a main line to supply irrigation water, while $20 \mathrm{~mm}$ for sub-main lines. Lateral lines were equipped with integrated compensating drippers with a discharge of $4 \mathrm{~L} \mathrm{~h}^{-1}$ each crop row. The spacing between lateral drip pipes was $0.75 \mathrm{~m}$, while spacing between emitters was $0.33 \mathrm{~m}$. Fertigation equipment used for drip fertigation treatments was Dosatron 16, with a plastic barrel as reservoir for concentrated fertilizer. Electrical Conductivity of the irrigation nutrient solution throughout the cultivation season was between $0.5-0.7 \mathrm{dS} \mathrm{m}^{-1}$. According to soil type and cultivation practice (Bošnjak, 1999), furrows with $0.40 \mathrm{~m}$ width and $0.15 \mathrm{~m}$ height were constructed for the control treatment. The source of water was of high quality (municipal water supply system for city of Skopje). The digital water flow meter was installed for measuring of irrigation application rate.

The first irrigation application rate for all treatments in the first and second experimental year was based on the soil moisture deficit that would be needed to bring the $0-60 \mathrm{~cm}$ soil layer to field capacity. In both the years, the irrigation program started immediately after the first irrigation application rate (around May 20 ${ }^{\text {th }}$ ) and according to experimental treatments designed for this study presented below. Last irrigation application rate was realized seven days before last harvest (around October $15^{\text {th }}$ ). The irrigation scheme of the experiment (treatment $\mathrm{DF}_{1}, \mathrm{DF}_{2}$ and $\varnothing_{\mathrm{B}}$ ) was scheduled according to long-term average (LTA) daily evapotranspiration of pepper in Skopje region (Table 2). LTA crop evapotranspiration was calculated by using FAO software CROPWAT for open field and by using crop coefficient $\left(\mathrm{K}_{c}\right)$ and stage length adjusted for local condition.

The irrigation scheme used in the experiment was designed according to randomized block design for experimental purposes with four treatments, each treatment replicated three time. Each plot (with a single replication) was designed with five rows of crop and five plants in each row. The size of each plot (replication) was $6.6 \mathrm{~m}^{2}$ (25 plants in $0.75 \mathrm{~m}$ of row spacing and with $0.35 \mathrm{~m}$ plant spacing in the row). The experimental treatments $\mathrm{DF}_{1}, \mathrm{DF}_{2}$ and $\emptyset_{\mathrm{B}}$ were set up according to the daily evapotranspiration rate, while $\mathrm{DF}_{3}$ was set up using soil matrix potential data from tensiometers. The idea was to investigate not only irrigation and fertilization regime, but also irrigation and fertilization frequency and their effect on pepper NFUE and yield. Therefore, the following experimental treatments were applied in this study: Drip fertigation according to daily evapotranspiration with application of water and fertilizer in every two days $\left(\mathrm{DF}_{1}\right)$; Drip fertigation according to daily evapotranspiration with application of water and fertilizer in every four days $\left(\mathrm{DF}_{2}\right)$; Drip fertigation scheduled with tensiometers $\left(\mathrm{DF}_{3}\right)$ with recommendations undertaken by Tekinel and Kanber (2002); Furrow irrigation according to daily evapotranspiration with application of water in every seven days and conventional fertilization $\left(\varnothing_{\mathrm{B}}\right)$. The daily evapotranspiration rate of $\mathrm{DF}_{1}$ and $\mathrm{DF}_{2}$ was decreased for $20 \%$ (coverage coefficient) as result of applied irrigation technique and regime, similarly to Xie et al. (1999).

Crop water use (ETP) and determination of soil water content

Crop water use during the growing season was determined using soil water balance method by direct measurements of soil moisture in the soil layer 0-100 cm (Bošnjak, 1999).

$\mathrm{ETP}=\mathrm{W}_{1}+1-\mathrm{W}_{2}$

ETP in equation 1 present the potential evapotranspiration $(\mathrm{mm}), \mathrm{W}_{1}$ is active soil moisture content at the beginning of vegetation, $I$ is irrigation water $(\mathrm{mm})$ and $W_{2}$ is active soil moisture content at the end of vegetation. As was mentioned above, our investigation was realized in experimental plastic house, where precipitations $(\mathrm{P})$ haven't influence on soil water income. Also, as result of controlled irrigation practice of drip and furrow irrigation treatments applied in the study, there were no excess irrigations or runoff during the irrigation seasons. Therefore, surface runoff (RO) and deep percolation (DP) were assumed to be zero. Also, the subsurface water and water transported upward by capillary rise (CR) haven't influence on water income in the root zone, and they were excluded from this estimation. The average ETP in treatments $\mathrm{DF}_{1}, \mathrm{DF}_{2}, \mathrm{DF}_{3}$ and $\emptyset_{\mathrm{B}}$ were 493, 492, 502 and $592 \mathrm{~mm}$ respectively. The average irrigation water has participated with almost $90 \%$ in ETP or 453 , 462,440 and $542 \mathrm{~mm}$ for treatments $\mathrm{DF}_{1}, \mathrm{DF}_{2}, \mathrm{DF}_{3}$ and $\varnothing_{\mathrm{B}}$ respectively. In order to determine the soil water content during the vegetation period, $30 \mathrm{~cm}$ soil layers were gravimetrically sampled to a depth of $60 \mathrm{~cm}$ (Bošnjak, 1999) every fourth day.

\section{NFUE}

Collecting and preparation of plant material and calculation of

Experimental plants were three plants in the middle of the experimental row from each replication and treatments and these plants were used for sampling and determination of NFUE. The harvest of fruits from the representative plants was carried out in the stage of technological maturity, part of the leaves, most often the older ones, where picked during the vegetation, the other part of the leaves and the entire stem were collected at the end of the vegetation. The procedure for laboratory preparation of the material was carried out according to the recommendations of IAEA (2001). The analysis for total nitrogen concentration in dry matter (\%N total) was done with micro-Kjeldahl method and the percentage of ${ }^{15} \mathrm{~N}$ excess in plant $\left(\%{ }^{15} \mathrm{~N}\right.$ excess) was measured with emission spectrometry in the laboratory for Agriculture and Biotechnology of IAEA in Seibersdorf, Austria. NFUE was calculated according to the recommendations of IAEA (2001) and according to the 
equations given below:

$$
\begin{aligned}
& \% \text { Ndff }=\frac{\% 15 \text { excess in plant }}{\%{ }_{15}^{15} \text { excess in fertilizer }} \times 100 \\
& \% \text { Ndfs }=100-\% \text { Ndff } \\
& N \text { yield }\left(\mathrm{kg} \mathrm{ha}^{-1}\right)=D M \text { yield }\left(\mathrm{kg} \mathrm{ha}^{-1}\right) \times \frac{\% N}{100} \\
& F N \text { yield }\left(\mathrm{kg} \mathrm{ha}^{-1}\right)=N \text { yield }\left(\mathrm{kg} \mathrm{ha}^{-1}\right) \times \frac{\% d f f}{100} \\
& \% N F U E=\frac{F N \text { yield }\left(\mathrm{kg} \mathrm{ha}^{-1}\right)}{\text { Rate of } \mathrm{N}} \times 100
\end{aligned}
$$

Here, \%Ndff is percentage of nitrogen derived from labelled fertilizer, $\%{ }^{15} \mathrm{~N}$ excess in plant is percentage of atom ${ }^{15} \mathrm{~N}$ excess in plant, $\%{ }^{15} \mathrm{~N}$ excess in fertilizer is percentage of atom ${ }^{15} \mathrm{~N}$ excess in fertilizer, \%Ndfs is percentage of nitrogen derived from soil, $\mathrm{N}$ yield $\mathrm{kg} \mathrm{ha}^{-1}$ is the total amount of $\mathrm{N}$ contained in the crop, DM yield $\mathrm{kg} \mathrm{ha}^{-1}$ is dry matter yield per unit area, $\% \mathrm{~N}$ is percentage of total $\mathrm{N}$ concentration in dry matter, FN yield $\mathrm{kg} \mathrm{ha}^{-1}$ is the amount of $\mathrm{N}$ fertiliser taken up by the crop, \%NFUE is nitrogen fertilizer use efficiency and Rate of $\mathrm{N}$ is amount of $\mathrm{N} \mathrm{ha}^{-1}$ in the form ${ }^{15} \mathrm{~N}$ labelled fertilizer.

\section{Data analysis}

Collected data were subjected to analyses of variance using $\mathrm{R}$ 3.1.3 statistical software. LSD test at $\mathrm{P} \leq 0.05$ was used to group the means per treatment when the F-test was significant.

\section{Results and Discussions}

\section{Soil moisture content variation}

Average soil moisture content variations for different irrigation and fertigation regimes in the present study are shown in Fig. 2. As shown in this figure, soil moisture content (SMC) in the top $60 \mathrm{~cm}$ soil depth in treatments $\mathrm{DF}_{1}$ and $\mathrm{DF}_{2}$ were relatively constant during all vegetation period as compared with $\varnothing_{\mathrm{B}}$. The SMC during the vegetation ranged from $28.71 \%$ to $30.72 \%$ and from $27.49 \%$ to $30.27 \%$ for treatment $\mathrm{DF}_{1}$ and $\mathrm{DF}_{2}$ respectively. On the other hand, SMC in $\mathrm{DF}_{3}$ shown more intensive fluctuation and gradually decreased values compared to $\mathrm{DF}_{1}$ and $\mathrm{DF}_{2}$. Soil moisture content during the vegetation ranged from $25.83 \%$ to $29.98 \%$. Such fluctuations in treatment $\mathrm{DF}_{3}$ are result of irrigation intervals, which in this case wary from eight to nine days at the beginning of vegetation and to five or six days during the flowering and mass fructification, and which according to obtained yields in this study proved to be less practical in intensely high temperatures. Sezen et al. (2006) indicated that higher frequency irrigation created favourable soil water environment for bell pepper growth and resulted in higher yields. The lowest SMC and stronger fluctuations in the present study were noted in treatment $\emptyset_{\mathrm{B}}$. The average SMC in both the years for $\varnothing_{\mathrm{B}}$ ranged from $23.68 \%$ to $29.64 \%$. Moreover, SMC in treatment $\varnothing_{\mathrm{B}}$ fell 5 times below treshhold ( $80 \%$ of FC), and due to soil water stress during mass fructification resulted in lower yield compared with drip fertigation treatments. Also, the results from present investigation correspond with those of Sezen et al. (2015), where drip irrigated pepper was compared with furrow and Tanaskovik et al. (2016), where drip fertigated tomato was compared with banded and furrow irrigated. For high pepper yields, an adequate water supply (Kirnak et al., 2016) and relatively moist soils are required during the total growing

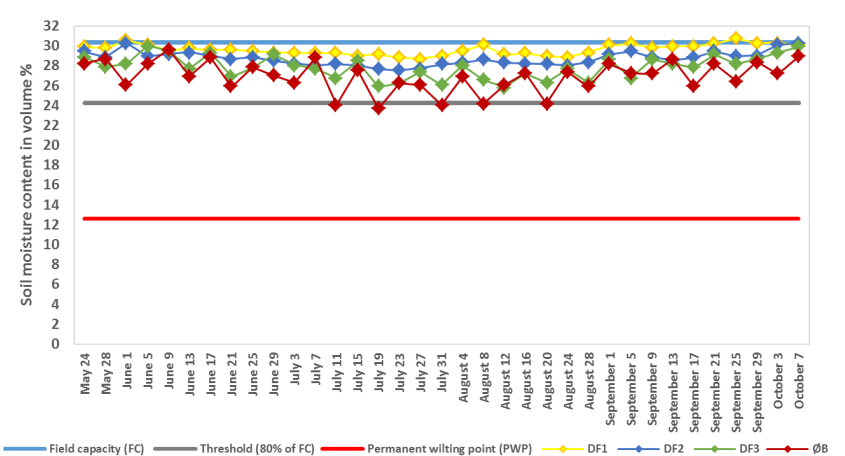

Fig. 2. Average soil moisture content variation during the vegetation

period (Shao et al., 2010; Sezen et al., 2014). Limited irrigation caused decreases yield and vegetative growth of bell pepper (Kurunc et al., 2011). Therefore, soil water should be maintained between $65 \%$ and $80 \%$ of FC to the first harvest (Dalla Costa and Gianquinto, 2002; Candido et al., 2009) and around $80 \%$ during mass fructification of pepper (Lazić et al., 2001; Shao et al., 2010).

Effect of irrigation and fertigation regime on pepper yield potential

The highest marketable average pepper yield of $73.46 \mathrm{t} \mathrm{ha}^{-1}$ was obtained in the treatment $\mathrm{DF}_{1}$, then comes the treatments $\mathrm{DF}_{2}$ with $70.54 \mathrm{tha}^{-1}$ and $\mathrm{DF}_{3}$ with $64.86 \mathrm{t} \mathrm{ha}^{-1}$, and then come the control treatment with the lowest yield of $56.56 \mathrm{t} \mathrm{ha}^{-1}$ (Table 3). All three treatments with drip fertigation show statistically significant differences at 0.05 level of probability when compared to the control treatment $\varnothing_{\mathrm{B}}$. The low marketable pepper yield in treatment $\varnothing_{\mathrm{B}}$ in our study may be associated with soil moisture stress (Dalla Costa and Gianquinto, 2002; Ferrara et al., 2011), inadequate soil moisture and nutrient content (Wiertz and Lenz 1987; Abayomi et al., 2012), especially inadequate water and soil nutrient procurement (Kuşçu et al., 2016) affected by irrigation and fertilization regime. Sezen et al. (2014) reported higher pepper yield in drip compared with furrow irrigation.

When we compared drip fertigation treatments, it was concluded that treatment $\mathrm{DF}_{3}$ (average at seven days drip fertigation) resulted in $8.8 \%$ to $13.3 \%$ lower pepper yield in comparison to $\mathrm{DF}_{2}$ and $\mathrm{DF}_{1}$ treatments. The results in our study are consistent with a number of other studies conducted on pepper and other vegetable crops where high frequency drip irrigation and fertigation improved yields (Tekinel and Kanber 2002; Sezen et al., 2006; Tanaskovik et al., 2011; Çolak et al., 2015). In almost similar growing density with those in our study and where a similar drip fertigation regime was applied to all experimental treatments, Jovicich et al. (2004) reported higher yield in 4 main shoots pruned pepper, while Daşgan and Abak (2003) reported better yield in 2 and 3 main shoots pruned pepper.

\section{Effect of the irrigation and fertilization regime on nitrogen} fertilizer use efficiency

The results presented in Table 4, showed a statistically significant total dry matter yield (DM yield) in drip fertigation treatments compared with control treatment $\emptyset_{\mathrm{B}}$. Similar results of total pepper DM in drip compared with furrow irrigation system reported Antony and Singandhupe (2004). In this context, González-Dugo et al. (2007) and Candido et al. 
Table 3. Average marketable pepper yields (in $\mathrm{t} \mathrm{ha}^{-1}$ )

\begin{tabular}{|c|c|c|c|c|}
\hline & $\mathrm{DF}_{1}$ & $\mathrm{DF}_{2}$ & $\mathrm{DF}_{3}$ & $\varnothing_{\mathrm{B}}$ \\
\hline Yield $\left(\mathrm{t} \mathrm{ha}^{-1}\right)$ & $73.46^{a}$ & $70.54^{a}$ & $64.86^{\mathrm{b}}$ & $56.56^{\mathrm{c}}$ \\
\hline Comparison with $\emptyset_{\mathrm{B}}$ in $\%$ & 129.9 & 124.7 & 114.7 & 100 \\
\hline Comparison with $\mathrm{DF}_{3}$ in \% & 113.3 & 108.8 & 100 & \\
\hline
\end{tabular}

*Values in rows followed by the same letter are not significantly different at the 0.05 probability level

Table 4. Nitrogen fertilizer use efficiency by pepper plant (fruit, stem, leaf and whole plant)

\begin{tabular}{|c|c|c|c|c|c|c|c|c|}
\hline Treatment & DM yield $t h a^{-1}$ & $\% \mathrm{~N}$ & $\begin{array}{l}\mathrm{N} \text { yield } \\
\mathrm{kg} \mathrm{ha}^{-1}\end{array}$ & $\begin{array}{l}\%^{15} \mathrm{~N} \\
\text { excess }\end{array}$ & $\% \mathrm{~N}$ dff & $\% \mathrm{~N} d f s$ & $\begin{array}{l}\text { FN yield } \\
\mathrm{kg} \mathrm{ha}^{-1}\end{array}$ & NFUE (\%) \\
\hline \multicolumn{9}{|c|}{ Fruit } \\
\hline$\overline{\mathrm{DF}_{1}}$ & $5.90^{\mathrm{a}}$ & $2.73^{a}$ & $161.07^{\mathrm{a}}$ & $0.404^{a}$ & $40.40^{\mathrm{a}}$ & $59.60^{\mathrm{a}}$ & $65.07^{\mathrm{a}}$ & $32.10^{\mathrm{a}}$ \\
\hline $\mathrm{DF}_{2}$ & $5.72^{\mathrm{a}}$ & $2.80^{\mathrm{a}}$ & $160.16^{a}$ & $0.375^{a}$ & $37.50^{\mathrm{a}}$ & $62.50^{\mathrm{a}}$ & $60.06^{\mathrm{ab}}$ & $29.63^{\mathrm{ab}}$ \\
\hline $\mathrm{DF}_{3}$ & $5.17^{\mathrm{b}}$ & $2.79^{a}$ & $144.24^{\mathrm{b}}$ & $0.357^{\mathrm{a}}$ & $35.70^{\mathrm{ab}}$ & $64.30^{\mathrm{ab}}$ & $51.49^{\mathrm{b}}$ & $25.40^{\mathrm{b}}$ \\
\hline$\varnothing_{\text {в }}$ & $4.46^{\mathrm{c}}$ & $2.64^{a}$ & $117.74^{\mathrm{c}}$ & $0.275^{\mathrm{b}}$ & $27.50^{\mathrm{b}}$ & $72.50^{\mathrm{b}}$ & $32.38^{\mathrm{c}}$ & $15.97^{\mathrm{c}}$ \\
\hline \multicolumn{9}{|c|}{ Stem } \\
\hline $\mathrm{DF}_{1}$ & $2.74^{\mathrm{a}}$ & $1.69^{a}$ & $46.31^{2}$ & $0.422^{\mathrm{ab}}$ & $42.20^{\mathrm{ab}}$ & $57.80^{\mathrm{ab}}$ & $19.54^{\mathrm{a}}$ & $9.64^{\mathrm{a}}$ \\
\hline $\mathrm{DF}_{2}$ & $2.72^{\mathrm{a}}$ & $1.66^{\mathrm{a}}$ & $45.15^{\mathrm{a}}$ & $0.432^{a}$ & $43.20^{\mathrm{a}}$ & $56.80^{\mathrm{a}}$ & $19.51^{\mathrm{a}}$ & $9.62^{\mathrm{a}}$ \\
\hline $\mathrm{DF}_{3}$ & $2.23^{\mathrm{b}}$ & $1.63^{\mathrm{a}}$ & $36.35^{\mathrm{b}}$ & $0.372^{\mathrm{ab}}$ & $37.20^{\mathrm{ab}}$ & $62.80^{\mathrm{ab}}$ & $13.52^{\mathrm{b}}$ & $6.67^{\mathrm{b}}$ \\
\hline$\varnothing_{\text {в }}$ & $1.90^{\mathrm{c}}$ & $1.46^{\mathrm{a}}$ & $27.74^{\mathrm{c}}$ & $0.325^{\mathrm{b}}$ & $32.50^{\mathrm{b}}$ & $67.50^{\mathrm{b}}$ & $9.02^{\mathrm{c}}$ & $4.45^{\mathrm{c}}$ \\
\hline \multicolumn{9}{|c|}{ Leaf } \\
\hline $\mathrm{DF}_{1}$ & $3.08^{a}$ & $3.97^{\mathrm{a}}$ & $122.28^{\mathrm{a}}$ & $0.419^{\mathrm{a}}$ & $41.90^{\mathrm{a}}$ & $58.10^{\mathrm{a}}$ & $51.23^{\mathrm{a}}$ & $25.28^{a}$ \\
\hline $\mathrm{DF}_{2}$ & $2.99^{\mathrm{a}}$ & $4.09^{\mathrm{a}}$ & $122.29^{\mathrm{a}}$ & $0.401^{\mathrm{a}}$ & $40.10^{\mathrm{a}}$ & $59.90^{\mathrm{a}}$ & $49.04^{\mathrm{a}}$ & $24.19^{\mathrm{a}}$ \\
\hline $\mathrm{DF}_{3}$ & $2.41^{\mathrm{b}}$ & $3.79^{\mathrm{a}}$ & $91.34^{\mathrm{b}}$ & $0.364^{\mathrm{ab}}$ & $36.40^{\mathrm{ab}}$ & $63.60^{\mathrm{ab}}$ & $33.25^{\mathrm{b}}$ & $16.40^{\mathrm{b}}$ \\
\hline$\varnothing_{\mathrm{B}}$ & $2.19^{\mathrm{b}}$ & $3.81^{\mathrm{a}}$ & $83.44^{\mathrm{b}}$ & $0.296^{\mathrm{b}}$ & $29.60^{\mathrm{b}}$ & $70.40^{\mathrm{b}}$ & $24.70^{\mathrm{b}}$ & $12.18^{\mathrm{b}}$ \\
\hline \multicolumn{9}{|c|}{ Whole plant } \\
\hline $\mathrm{DF}_{1}$ & $11.72^{\mathrm{a}}$ & $2.80^{\mathrm{a}}$ & $329.65^{\mathrm{a}}$ & $0.415^{\mathrm{a}}$ & $41.50^{\mathrm{a}}$ & $58.50^{\mathrm{a}}$ & $135.85^{\mathrm{a}}$ & $67.02^{\mathrm{a}}$ \\
\hline $\mathrm{DF}_{2}$ & $11.43^{\mathrm{a}}$ & $2.85^{\mathrm{a}}$ & $327.60^{a}$ & $0.403^{a}$ & $40.27^{\mathrm{a}}$ & $59.73^{a}$ & $128.60^{\mathrm{a}}$ & $63.45^{\mathrm{a}}$ \\
\hline $\mathrm{DF}_{3}$ & $9.81^{b}$ & $2.74^{\mathrm{ab}}$ & $271.93^{b}$ & $0.364^{\mathrm{ab}}$ & $36.43^{\mathrm{ab}}$ & $63.57^{\mathrm{ab}}$ & $98.26^{\mathrm{b}}$ & $48.48^{b}$ \\
\hline$\varnothing_{\mathrm{B}}$ & $8.55^{c}$ & $2.64^{\mathrm{b}}$ & $228.92^{\mathrm{c}}$ & $0.299^{\mathrm{b}}$ & $29.87^{b}$ & $70.13^{\mathrm{a}}$ & $66.09^{c}$ & $32.61^{c}$ \\
\hline
\end{tabular}

${ }^{*}$ Values in rows followed by the same letter are not significantly different at the 0.05 probability level

(2009) indicated that continuous deficit of soil moisture affects the decrease of pepper DM yield. Moreover, in the present study, the drip fertigation frequency at two and four day's points to differences in the yield of total dry matter compared with $\mathrm{DF}_{3}$ (average at seven days drip fertigation). The treatment $\mathrm{DF}_{3}$ has noted a yield lower by $1.91 \mathrm{t} \mathrm{ha}^{-1}$ in comparison to $\mathrm{DF}_{1}$, i.e. by $1.62 \mathrm{t}$ ha ${ }^{-1}$ in comparison with $\mathrm{DF}_{2}$, and the differences were statistically significant at 0.05 level of probability. Similar results were achieved individually by leaf, stem and fruit. Cukaliev et al. (2008) and Çolak et al. (2015) reported better total tomato and eggplant DM yield in higher compared with lower frequency drip irrigation.

From the analyses of the total nitrogen percentage $(\% \mathrm{~N}$ total) of dry matter yield by individual plant parts, statistically significant differences were not noted among any of the treatments. However, as result of total DM yield differences between the treatments, the highest value of total nitrogen percentage by whole plant were noted in treatments $\mathrm{DF}_{2}$ and $\mathrm{DF}_{1}$ with 2.85 and $2.80 \%$, then comes the treatment $\mathrm{DF}_{3}$ with $2.74 \%$, and then comes the $\varnothing_{\mathrm{B}}$ with the lowest percentage from 2.64. Treatments $\mathrm{DF}_{2}$ and $\mathrm{DF}_{1}$ have shown statistically significant difference compared with $\mathrm{DF}_{3}$ and $\varnothing_{\mathrm{B}}$. Despite the fact that by laboratory analysis a lower total nitrogen percentage was determined in treatment $\mathrm{DF}_{1}$ compared with $\mathrm{DF}_{2}$, due to the high total $\mathrm{DM}$ yield, treatment $\mathrm{DF}_{1}$ has again shown the best results, but this time for the total amount of nitrogen contained in the crop ( $\mathrm{N}$ yield $\mathrm{kg} \mathrm{ha}^{-1}$ ), or about $329.65 \mathrm{~kg} \mathrm{ha}^{-1}$. The lowest $\mathrm{N}$ yield $\mathrm{kg} \mathrm{ha}^{-1}$ was found in treatment with furrow irrigation and conventional fertilization $\left(\varnothing_{\mathrm{B}}\right)$ with $228.92 \mathrm{~kg}$ $\mathrm{ha}^{-1}$ or $44 \%$ less in comparison with the treatment $\mathrm{DF}_{1}$. All treatments under drip fertigation in present study showed a statistically significant difference compared to control treatment $\varnothing_{\mathrm{B}}$. And many other authors have noted a higher total nitrogen percentage of dry matter yield, as well as higher total amount of nitrogen contained in the crop in treatments with drip fertigation compared to conventional application: Halitligil et al. (2002) in several vegetable crops (pepper, tomatoes, cucumber, melon), Sagheb and Hobbi (2002) and Cukaliev et al. (2008) in tomatoes. Also, our results show similar situation regarding the amount of nitrogen contained by individual plant parts. Generally, this effect of drip fertigation treatments is presumably due to direct application of water and fertilizer into the small volume of soil where the active crop roots are lumped and there are minimal chances for leaching of nutrients, especially of nitrogen. If nutrients are applied outside the wetted soil volume they are generally not available for crop use (Haynes, 1985). In the present study, we have documented that drip fertigation frequency have influence on total nitrogen uptake too. Namely, the treatments $\mathrm{DF}_{1}$ and $\mathrm{DF}_{2}$ show $21.2 \%$ and $20.5 \%$ higher total nitrogen uptake compared to treatment $\mathrm{DF}_{3}$. In this context, Bar-Tal et al. (2015) indicated that high concentrations of nutrients used in prolongated fertigation lead to fluctuations from high or even excessive concentration immediately after irrigation in the rhizosphere to deficit levels as time proceeds. Therefore, the frequent replenishment of the nutrients is required in drip irrigation (Hagin et al., 2002).

The highest values for the percentage of nitrogen derived from the urea fertilizer (\% $\mathrm{N}$ d.f.f.) by whole plant was observed in different drip fertigation treatments, i.e. 41.50, 40.27, and 36.43 for $\mathrm{DF}_{1}, \mathrm{DF}_{2}$ and $\mathrm{DF}_{3}$, respectively, which can be ascribed to the higher percentage of ${ }^{5} \mathrm{~N}$ atom excess found in 
530

the same treatments. However, only the treatments $\mathrm{DF}_{1}$ and $\mathrm{DF}_{2}$ compared to the control treatment $\varnothing_{\mathrm{B}}$ have shown statistically significant difference regarding the ${ }^{15} \mathrm{~N}$ atom excess and $\% \mathrm{~N}$ d.f.f. by the whole plant, which is closely correlated to the results on the percentage of ${ }^{15} \mathrm{~N}$ atom excess obtained individually by plant parts. Similar effect of drip fertigation on the $\% \mathrm{~N}$ d.f.f. in pepper are reported by Halitligil et al. (2002). Furthermore, our results shown a high percentage of nitrogen derived from the soil (\% $\mathrm{N}$ d.f.s.) in almost all treatments, which can be ascribed to application of part of nutrients before transplanting of pepper and utilization of these nutrients from the soil during the vegetation. However, the control treatment $\varnothing_{\mathrm{B}}$ with $70.13 \%$ has shown the highest $\% \mathrm{~N}$ d.f.s., which is result of the method of application of the fertilizer. According to Gardner and Roth (1984), with drip fertigation the participation of the soil as nutrient reservoir is reduced in comparison with conventional application. The amount of nitrogen fertiliser taken up by the whole plant in our study is in relation with previously mentioned results. Namely, it can be concluded that treatments $\mathrm{DF}_{1}$ and $\mathrm{DF}_{2}$ with 135.85 and $128.60 \mathrm{~kg} \mathrm{ha}^{-1}$, respectively, have shown the highest values. As result of lower irrigation frequency (average at seven days), the treatment $\mathrm{DF}_{3}$ has shown by $37.59 \mathrm{~kg} \mathrm{ha}^{-1}$ less FN yield kg ha ${ }^{-1}$ compared to $\mathrm{DF}_{1}$, i.e. by $30.34 \mathrm{~kg} \mathrm{ha}{ }^{-1}$ with $\mathrm{DF}_{2}$, and the differences were statistically significant. Such similar tendency, except in the fruit, was also noted separately for each part of the plant. Furthermore, statistically significant effect of all drip fertigation treatments compared with furrow irrigation and conventional fertilization treatment was observed for FN yield $\mathrm{kg} \mathrm{ha}^{-1}$ by the whole plant and individually by plant parts, except for the leaf in the treatment $\mathrm{DF}_{3}$.

From the data obtained by calculating the percentage of NFUE for whole plants, once again it is clear that the treatments under drip fertigation indicated the best results with a statistically significant difference in comparison with $\varnothing_{\mathrm{B}}$. Namely, the percentage of NFUE was 67.02, 63.45, 48.48 and 32.61 for the treatments $\mathrm{DF}_{1}, \mathrm{DF}_{2}, \mathrm{DF}_{3}$ and $\emptyset_{\mathrm{B}}$, respectively. If our results are presented in comparative values, then NFUE in the treatments $\mathrm{DF}_{1}$ and $\mathrm{DF}_{2}$ was almost $100 \%$ higher in comparison with $\emptyset_{\mathrm{B}}$. Also, the treatment $\mathrm{DF}_{3}$ was obtained more than $48 \%$ higher NFUE in comparison with treatment $\varnothing_{\mathrm{B}}$, and irrigation frequency was very similar and sometimes a bit longer compared with $\varnothing_{\mathrm{B}}$. Such similar tendency, except in leaf material of treatment $\mathrm{DF}_{3}$, was also noted separately for each part of the plant. In this context, Halitligil et al. (2002) reported significantly increased percentage of NFUE in drip fertigation pepper compared to the soil application of fertilizer at the same level. The same authors gives similar results with tomato, cucumber, melon and eggplant. Also, the results from our investigation correspond with those of Miller et al. (1981), Sagheb and Hobbi (2002), Hebbar et al. (2004), Cukaliev et al. (2008) and Fan et al. (2014) where nitrogen was used more efficiently in drip fertigation than when tomato crop was banded and furrow or flooded irrigated or banded and drip irrigated. Yasuor et al. (2013) reported that higher concentration of nitrogen in irrigation water significantly influenced his uptake in whole plant and among plants organ. According to Drechsel et al. (2015), improvements in nutrient use efficiency should not be viewed only as result of fertilizer management, because nutrient plant use is closely related with soil water stress and water management. Water stress led to significant decrease of nitrogen absorption by pepper plant
(Candido et al., 2009). Furthermore, in the present study we have found that drip fertigation frequency at two and four day's resulted in higher NFUE compared with $\mathrm{DF}_{3}$. Namely, the treatments $\mathrm{DF}_{1}$ and $\mathrm{DF}_{2}$ show 38.2 and $30.9 \%$ higher NFUE for whole plants than $\mathrm{DF}_{3}$. The results are statistically significant at 0.05 level of probability. Similarly, except fruit material in treatment $\mathrm{DF}_{2}$, was also observed separately for each part of the plant. The lower NFUE in treatment $\mathrm{DF}_{3}$ can be attributed on prolongated drip fertigation frequency proceeded with pretty higher quantity of water and nutrients in comparison with $\mathrm{DF}_{1}$ and $\mathrm{DF}_{2}$. Papadopoulos (1996) reported that with excess irrigation, since water is enriched with fertilizers, substantial loss of fertilizers particularly of nitrogen is expected to occur in soil. Thus, high fertigation and/or irrigation frequency may represent a strategy to increase $\mathrm{N}$ uptake efficiency in many vegetable crops (Benincasa et al., 2011; Farneselli et al., 2015).

In general, according to the obtained results from our study, it can be concluded that the drip fertigation treatments, especially the treatments of two and four day's frequency, resulted not only in increasing yields, but also NFUE. This is especially important for environment protection from nitrogen pollution, especially in intensive agriculture, where water and nutrients are the most utilized resources for obtaining greater yields per unit area. A number of reports (Li et al., 2001; Zhu et al., 2005; Stagnari and Pisante 2012; Ouzounidou et al., 2013) indicated that nitrogen is one of the major potential environmental contaminant and, hence, increasing nitrogen use efficiency is central to environmental responsibility and agricultural sustainability (Fageria and Baligar, 2005). Therefore, proper fertilizer application in right time, right rate and right place (Roberts, 2008) will increase crop yields and nutrient efficiency, as well as farmer benefits and protection of environment.

\section{Conclusions}

The results of this study clearly have shown that increased NFUE and pepper yield depend on irrigation and fertilization regimes. Obviously, NFUE and pepper yield were significantly increased with the application of nitrogen fertilizer through drip irrigation system as compared to the conventional application and furrow irrigated. If this principal is not followed, it will lead to lower pepper yield and decreased nitrogen fertilizer use efficiency, with risk for environmental contamination. Moreover, a high frequency drip fertigation with continuous feeding are highly recommended for maximising pepper yield and NFUE. Generally, to reach acceptable pepper yield with high NFUE, we recommend drip fertigation with a frequency of two to four days combined with two main shoots of pruned pepper in order to increase farmer's income and to minimize the environmental impact of nitrogen from pepper production.

\section{Acknowledgement}

This work was partly supported by FAO/LAEA Regional Technical Co-operation Project for Europe (RER/5/011). The authors would like to thank Soil and Water Management and Crop Nutrition Section of the International Atomic Energy Agency for their technical support and help with laboratory analysis of the data presented in this study. 


\section{References}

Abayomi YA, Aduloju MO, Egbewunmi MA, Suleiman BO (2012). Effects of soil moisture contents and rates of NPK fertilizer application on growth and fruit yields of pepper (Capsicum spp.) genotypes. International Journal of AgriScience 2(7):651-663.

Aladenola O, Madramootoo C (2014). Response of greenhouse-grown bell pepper (Capsicum annuum L.) to variable irrigation. Canadian Journal of Plant Science 94:303-310.

Antony E, Singandhupe RB (2004). Impact of drip and surface irrigation on growth, yield and WUE of capsicum (Capsicum annum L.). Agricultural Water Management 65:121-132.

Bar-Tal A, Fine P, Yermiyahu U, Ben-Gal A, Hass A (2015). Practices that simultaneously optimize water and nutrient use efficiency, Israeli experiences in fertigation and irrigation with treated wastewater. In: Drechsel $\mathrm{P}$ et al. (Eds). Managing water and fertilizer for sustainable agricultural intensification. IFA, IWMI, IPNI, IPI, Paris pp 209-241.

Benincasa P, Guiducci M, Tei F (2011). The nitrogen use efficiency: Meaning and sources of variation-case studies on three vegetable crops in Central Italy. Hort Technology 21(3):266-273.

Bošnjak Đ (1999). Navodnjavanje poljoprivrednih useva. [Irrigation of Agricultural Crops]. University of Novi Sad, Faculty for Agriculture, NoviSad.

Candido V, Miccolis V, Rivelli AR (2009). Yield traits and water and nitrogen use efficiencies of bell pepper grown in plastic-greenhouse. Italian Journal of Agronomy 3: 91-100.

Cetin O, Akinci C (2015). Effects of drought on optimizing nitrogen use of winter wheat in a semi arid region. Agriculture \& Forestry. doi: 10.17707/AgricultForest.61.1.36.

Çolak BY, Yazar A, Çolak I, Akça H, Duraktekin G (2015). Evaluation of crop water stress index (CWSI) for eggplant under varying irrigation regimes using surface and subsurface drip systems. Agriculture and Agricultural Science Procedia 4:372-382.

Cukaliev O, Tanaskovik V, Kanwar RS, Heng Kheng L, Mukaetov D (2008). Irrigation and fertigation effects on nitrogen use efficiency and tomato yield. International Agricultural Engineering Journal 17:19-26.

Daşgan YH, Abak K. (2003). Effects of plant density and number of shoots on yield and fruit characteristics of peppers grown in glasshouses. Turkish Journal of Agriculture and Forestry 27(1):29-35.

Dalla Costa L, Gianquinto G (2002). Water stress and waterable depth influence yield, water use efficiency, and nitrogen recovery in bell pepper: lysimeter studies. Australian Journal of Agricultural Research 53:201210.

Delfine S, Tognetti R, Loreto F, Alvino A (2002). Physiological responses and growth responses to water stress in field-grown bell pepper (Capsicum annum L.). Journal of Horticulture Science and Biotechnology 77:697-704.

Dorji K, Behboundian M H, Zegbe-Dominguez JA (2005). Water relations, growth, yield and fruit quality of hot pepper under deficit irrigation and partial rootzone drying. Scientia Horticulturae 104:137149.

Drechsel P, Heffer P, Magen H, Mikkelsen R, Singh H, Wichelns D (2015). Managing water and nutrients to ensure global food security, while sustaining ecosystem services. In: Drechsel P et al. (Eds). Managingwater and fertilizer for sustainable agricultural intensification. IFA, IWMI, IPNI, IPI, Paris pp 1-7.

Fageria NK, Baligar VC (2005). Enhancing nitrogen use efficiency in crop plants. Advances in Agronomy 88:97-185.

Fan Z, Lin S, Zhang X,Jiang Z, Yang K, Jian D,... Wang J (2014). Conventional flooding irrigation causes an overuse of nitrogen fertilizer and low nitrogen use efficiency in intensively used solar greenhouse vegetable production. Agricultural Water Management 144:11-19.

Farneselli M, Benincasa P, Tosti G, Simonne E, Guiducci M, Tei F (2015). High fertigation frequency improves nitrogen uptake and crop performance in processing tomato grown with high nitrogen and water supply. Agricultural Water Management 154:52-58.

Ferrara A, Lovelli S, Di Tommaso T, Perniola M (2011). Flowering, growth and fruit setting in greenhouse bell pepper under water stress. Journal of Agronomy 10(1):12-19.

Gardner BR, Roth RL (1984). Applying nitrogen in irrigation water. In: Hauck RD (Ed): Nitrogen in crop production. American Society of Agronomy, Madison pp 493-506.

González-Dugo V, Orgaz F, Fereres E (2007). Response of pepper to deficit irrigation for paprika production. Scientia Horticulturae 114:77-82.

Hagin J, Sneh M, Lowengart-Aycicegi A (2002). Fertilization through Irrigation. In: Johnston AE (Ed). Research Topics No. 23, International Potash Institute, Basel.

Halitligil MB, Akin AI, Kislal H, Ozturk A, Deviren A (2002). Yield, nitrogen uptake and nitrogen use efficiency by tomato, pepper, cucumber, melon and eggplant as affected by nitrogen rates applied with drip-irrigation under greenhouse conditions. In: Water balance and fertigation for crop improvement in West Asia, IAEA, Vienna, Austria pp 99-110.

Haynes RJ (1985). Principles of fertilizer use for trickle irrigated crops: Fertilizer research 6. Martinus Nijhoff/Dr W. Junk Publishers, Dordrecht, Netherlands:235-255.

Hebbar SS, Ramachandrappa BK, Nanjappa HV, Prabhakar M (2004). Studies of NPK drip fertigation in field grown tomato (Lycopersicon esculentum Mill.).European Journal of Agronomy21:117-127.

International Atomic Energy Agency (2001). Use of isotope and radiation methods in soil and water management and crop nutrition. IAEA, Vienna, Austria.

Jovicich E, Cantliffe DJ, Stoffella PJ (2004). Fruit yield and quality of greenhouse-grown bell pepper as influenced by density, container and trellis system. Hort Technology 14(4):507-513.

Kirnak H, Gökalp Z, Demir H, Kodal S, Yildirim E (2016). Paprika pepper yield and quality as affected by different irrigation levels. Tarmm Bilimleri Dergisi-Journal of Agricultural Sciences 22:77-88.

Kubešová K, Balík J, Černý J, Sedlár O, Pelková L (2014). The influence of fertilization by controlled ammonium nutrition (Cultan) on maize yield, $\mathrm{N}$ uptake and content of nitrates in soils with a high content of mineral nitrogen. Romanian Agricultural Research 31:167-174.

Kurunc A, UnlukaraA, Cemek B (2011). Salinity and drought affect yield response of bell pepper. Acta agriculturae scandinavica section b-soil and plant science 61(6):514-522.

Kuş̧̧ H, Turhan A,Özmen N,Aydınol P,Demir OA (2016). Response of red pepper to deficit irrigation and nitrogen fertigation. Archives of Agronomy and Soil Science 62(10):1396-1410. 
532

Lazić B, Djurovka M, Marković V, Ilin Ž (2001). Vegetable Production (2 ${ }^{\text {nd }}$ ed).NoviSad, Tampograf.

Li JH, Zhu JH, Zhnag XS, Meng XX, Chen Q, Li XI, Zhnag FS (2001). Nitrate leaching loss from soil and nutrient utilization by tomato in protected field. Chines Journal of Applied and Environmental Biology 7:126-129.

Miller RJ, Rolston DE, Rauschkolb RS, Wolfe DW (1981). Labelled nitrogen uptake by drip-irrigated tomatoes. Agronomy Journal 73:265270.

Ouzounidou G, Paschalidis C, Petropoulos A, Koriki A, Zamanidis P, Petridis A (2013). Interaction of soil moisture and excess of boron and nitrogen on lettuce growth and quality. Horticultural Science 40(3):119-125.

Papadopoulos I (1996). Micro-irrigation systems and fertigation. In: Pereira LS et al. (Ed). Sustainability of Irrigated Agriculture. Kluwer Academic Publisherspp 309-322.

Penella C, Nebauer SG, López-Galarza S, San Bautista A, RodriguezBurruezo A, Calatayud A (2014). Evaluation of some pepper genotypes as rootstocks in water stress conditions. Horticultural Science 41(4):192200.

R Core Team (2013). R: A language and environment for statistical computing. R Foundation for Statistical Computing. Retrieved 2016 Mar 10 from http://www.R-project.org/.

Roberts LT (2008). Improving nutrient use efficiency. Turkish Journal of Agriculture and Forestry 32(3):177-182.

Rubio F, Flores P, NavaroJM, Martinez V (2003). Effects of Ca2+, K+ and cGMPon Na+ uptake in pepper plants. Plant Science 165:1043-1049.

Sagheb N, Hobbi MS (2002). Field evaluation of urea fertilizer and water use efficiency by tomato under trickle fertigation and furrow irrigation in Iran. In: Water balance and fertigation for crop improvement in West Asia, IAEA Vienna, Austria pp 3-13.

Sezen SM, Yazar A, Salim E (2006). Effect of drip irrigation regimes on yield and quality of field grown bell pepper. Agricultural Water Management 81:115-131.

Sezen SM, Yazar A, Dasgan Y, Yucel S, Akyldız A, Tekin S, Akhoundnejad $\mathrm{Y}$ (2014). Evaluation of crop water stress index (CWSI) for red pepper with drip and furrow irrigation under varying irrigation regimes. Agriculture and Water Management 143:159-70.

Sezen SM,Yazar A,Şengül H,Baytorun N,Daşgan Y,Akyildiz A,... Gügercin Ö(2015).Comparison of drip- and furrow-irrigated red pepper yield, yield components, quality and net profit generation. Irrigation and Drainage 64:546-556.
Shao GC, Liu N, Zhang ZY, Yu SE, Chen C. (2010). Growth, yield and water use efficiency response of greenhouse-grown hot pepper under Time-Space deficit irrigation. Scientia Horticulturae 126(2):172-179.

Smatanová M, Richter R, Hlušek J (2004): Spinach and pepper response to nitrogen and sulphur fertilization. Plant, Soil and Environment 50(7):303-308.

Stagnari F, Pisante M (2012). Slow release and conventional N fertilizers for nutrition of bell pepper. Plant, Soil and Environment 58(6):268-274.

State Statistical Office (2015). Statistical yearbook of R Macedonia Retrieved 2016Jan 13 from http://wwwstatgov.mk/Publikacii/PDFSG2015/10Zemjodelstro.

Tanaskovik V, Cukaliev O, RomićD, Ondrasek G (2011). The influence of drip fertigation on water use efficiency in tomato crop production. Agriculture ConspectusScientificus 76(1):57-63.

Tanaskovik V, Cukaliev O, Markoski M, Mitkova T, Shutoska VM (2016). Soil moisture dynamics in different irrigation regimes of tomato crop. The Journal Agriculture \& Forestry. doi: 10.17707/AgricultForest.62.1.43.

Tekinel O, Kanber R (2002). Trickle irrigation experiments in Turkey. In: Özay M, Biçak AH (Eds). Modern and Traditional Irrigation Technologies in the Eastern Mediterranean. Ottawa, Canada, International Development Research Centre pp 27-72.

Yasuor H, Ben-Gal A, Yermiyahy U, Beit-Yannai E, Cohen S (2013). Nitrogen management of greenhouse pepper production: Agronomic, nutritional, and environmental implications. HortScience 48(10):12411249.

Wiertz R, Lenz F (1987). The growth and yield of pepper (Capsicum annum $L$.) depending on water and nutrient supply. Gartenbauwissenschaft 52:3945.

WRB (2015): World reference base for soil resources 2014.FAO, Rome.

Zapata F, Christian $\mathrm{H}$ (1997). Role of isotopes in mineral plant nutrition studies. Romanian Agricultural Research 7-8:49-53.

Zhu JH, Li XL, Christie P, LiJL (2005). Environmental implications of low nitrogen use efficiency in excessively fertilized hot pepper (Capsicum frutescens L.) cropping systems. Agriculture, Ecosystems and Environment 111:70-80.

Xie J, Cardenas ES, Sammis WT, Wall MM, Lindsey LD, Murray LW (1999). Effects of irrigation method on chili pepper yield and Phytophtora root rot incidence. Agricultural Water Management 42:127-142. 